\title{
The Role of Cross-Border Healthcare, Part of the Europe 2020 Strategy, in the Context of the Standardization of the Legislation at European Level
}

\author{
Cristina Luiza Erimia \\ *Ovidius University of Constanta, Faculty of Pharmacy, Campus Corp B, University Alley Nr. 1, Constanta
}

Rodica Sîrbu

General Issues: Legal Social Sciences: Issues of identity and globalization sirbu-27@yahoo.com

\section{Doi:10.5901/ajis.2015.v4n1s2p37}

\begin{abstract}
Because the right of EU citizens to be treated abroad was recognized by the Court of Justice of the European Union in several specific cases, starting with decisions dating back more than a decade, these decisions becoming part of the European acquis, this Article reviews the way in which the judgments of the Court of Justice of the European Union were refined within Directive 2011/24/EU. In the field of cross-border medical services, a certain overlap is somehow reached between the law of the Union and the national law, so that European law in many cases is essentially limited to indicating a binding objective, i. e. the achievement of the free movement of citizens patients and their equal treatment, regardless of nationality, in relation to national authorities, while preserving the competence of the member states. Against this overlap and given that the European Commission has established the role of health as part of the 2020 strategy, the article aims to analyse how Romania obliged to submit to the regulatory framework imposed by primary and secondary legislation, manages to ensure the sustainability of the current model of the healthcare system, in order to increase its efficiency and effectiveness.
\end{abstract}

Keywords: European Union, patients' rights, cross-border healthcare, the case law of the Court of Justice of the European Union, the standardization of European law, European health strategy

\section{Introduction}

Article 35 of the Charter of Fundamental Rights of the European Union [1] provides that: „Everyone has the right of access to preventive health care and the right to benefit from medical treatment under the conditions established by national laws and practices. A high level of human health protection shall be ensured in the definition and implementation of all Union policies and activities."

In exercising the powers which have been conferred in the interpretation of EU law, the Court of Justice of the European Union has developed over time a rich case law which has been refined with each application for a preliminary judgment submitted to the Court by the courts of the Member States. Thanks to the very rich case law in this area, the right of EU citizens to use free of constraints cross-border healthcare, which is generally known by the term "patient mobility", could be clearly outlined.

The Court has paved the way for the implementation of the right recognized at Article 35 of the Charter of Fundamental Rights of the European Union for every person to have access to preventive healthcare and to benefit from medical treatment. Through the case law of the Court, restrictions could be eliminated in the form of national regulations, which stood in the way of creating an internal market in healthcare delivery.

In our opinion, from the constant case law of the Court has have arisen certain important principles for the conditions in which, in accordance with the provisions on the freedom to provide services, patients are entitled to receiving medical care in other Member States and to the reimbursement of these treatment by the health insurance system to which they belong.

The principles developed in that case law were considered components of the acquis of the EU, which the European legislator has taken into account in the development of Directive 2011/24/EU of the European Parliament and of the Council of 9 March 2011 on the application of patients' rights in cross-border healthcare [2]. 


\section{Theory}

As part of the wider framework of services of general interest to the Union, health systems are a central component of social protection, and contribute both to social cohesion and social justice and to the sustainable development of the European Union.

As stated in the Council Conclusions on Common values and principles in European Union Health Systems, "health is a value in itself" [3], also being a prerequisite for the economic prosperity of the Union. Human health affects economic performance in terms of productivity, employment, human capital and public spending.

In this regard, the 2013 report on growth and cohesion [4] recognizes the role of healthcare in promoting social inclusion and combating poverty. To achieve the strategic objectives of the Union, providing access to high quality health care and the more efficient use of public resources, the document recommends reforming the health systems in order to ensure their profitability and sustainability, and its performance assessment.

The Strategy for Sustainable Development [5] of the European Union cannot be achieved without investment in health, ensuring in this way, a smart, sustainable and inclusive growth of national health systems.

Investing in health helps the Union to overcome the challenges identified in the EU Health Strategy [6], which were worsened by the economic crisis: an aging population, increasing chronic disease, a greater demand for health and the high cost of technological progress.

Establishing the role of health as part of the 2020 strategy, the Commission has shown that the relatively large share of healthcare expenses in the total public expenditure, combined with the need for fiscal consolidation across the EU, requires more efficiency and effectiveness to ensure the sustainability of current models of health system [7].

In order to remove the restrictions on the freedoms of European citizens, the cross-border healthcare directive creates a standard of protection at EU level within the harmonization of national policies in the field and targets the provision of healthcare services, thus ensuring patient mobility and the freedom of provision of health services. The directive regulates the provision of health services, irrespective of the organization, financing and delivery of these services.

\section{Results and Discussions}

As healthcare was excluded from the Directive 2006/123/EC [8] on services in the internal market, it has become imperative, in the European legal context, that these aspects be addressed through a legal instrument through which the principles established by the Court of Justice, on a case by case basis, be applied generally and effectively.

The right of EU citizens to get treated abroad was recognized by the Court of Justice of the European Union in several specific cases, starting with decisions dating back more than a decade, these decisions becoming part of the European acquis. However, individual decisions of the Court have not been assimilated coherently by national legislations, practically existing many situations in which patients were forced to solve problems of access to treatment abroad on their own by taking the entire legal route to the Court of Justice. Unfortunately, often the Court's decision came only after the patient's death, although a saving treatment would have been possible in a Member State other than that of residence.

Given the fact that at European level, planned and emergency treatment costs abroad represent only about $1 \%$ of public expenditure for healthcare [9], the simplification of the access procedure to cross-border medical services has become a moral imperative.

The problem of the legislative gap between Member States has become more visible with the adoption of the Treaty of Lisbon [10]. Treaty requires common standards at the level of social and medical assistance (Articles 34 and 35) and explicitly encourages, in particular, "cooperation between the Member States to improve the complementarity of their health services in cross-border areas. " (article 152). Complementary to the rights of citizens under the Treaty, has emerged the need for a European law that clarifies the responsibilities of Member States towards the patients.

The road towards the harmonization of medical services in Europe, opened by the introduction of the European Health Insurance Card, ought to continue with a pan-European development of patients' rights. From the earliest days of European integration and to date, the European institutions have actively promoted intra-European movement. The initiative to introduce a European Health Insurance Card to replace the prior necessary documents to access medical treatment during a temporary stay in another country falls within the same general phenomenon.

Since around the values expressed by the case law of the Court of Justice of the European Union there have been a number of uncertainties, which made them difficult to apply in practice, this development of patients' rights did not occur 
$a b$ initio, requiring the intervention of the European legislator to clarify the situation through a directive to support the provision of cross-border healthcare, both for the benefit of patients and of the national health service.

- In the field of cross-border medical services, a certain overlap is somehow reached between the law of the Union and the national law, so that European law in many cases is essentially limited to indicating a binding objective, i. e. the achievement of the free movement of citizens patients and their equal treatment, regardless of nationality, in relation to national authorities, while preserving the competence of the member states.

Against this overlap member states are obliged to submit to the regulatory framework imposed by primary and secondary legislation, to the extent that they are not allowed to violate EU law when exercising their powers.

Important institution of the European Union, the Court of Justice is the one that assesses the scope of the EU legal framework established by Article $49 \mathrm{EC}$ for the exercise of the competences of the Member States. It is also incumbent on the Court, assigned by the founding treaties, that by the interpretation given to a provision of European law, to clarify and specify its meaning and scope, such as to be understood and applied from the time of its entry into force.

The main principles proclaimed by Directive 2011/24/EU law have their legal source in a long series of cases in which the Court identified the limits imposed by the EU legislation on the restrictions in Member States of the right of patients to use medical services across national borders within the European internal market.

Thus, patients citizens are free to choose the Member State of the European Union and the preferred institution for medical treatment, social insurance offices in the State of residence assuming treatment costs in the same proportion as in at national level.

The European regulatory framework, aiming a new scheme of monitoring the services provided, was created precisely to enhance the quality and safety of healthcare services. The free movement of patients, without the legal force of European regulation, would have produced a competition between the health systems of the Member States in order to attract more patients. There is the risk that the free access to cross-border medical services may produce a drop in the price of medical services throughout the European Union to the detriment of the quality of health services.

The new cross-border healthcare system favours rare disease patients, whose treatment requires costly investments in research. The existence on the European internal market of health services of specialized hospitals on these diseases prevents the waste of resources due to the parallel investment in equipment and research and also provides for closer cooperation between Member States in terms of health.

The Directive clarifies the rights of citizens to access safe and good quality treatment across the EU and its reimbursement. Europeans prefer to receive healthcare close to home: no one wants to travel further than they should when they are ill. However, sometimes people have to go abroad, because experience or the medical care they need is not available within the national borders. Or simply because the nearest hospital is across the border.

However, from the application of the provisions of the Directive are exempted certain health care services such as, for example, long-term services, whose purpose is to support people who need help with daily routine tasks.

For OECD, long-term care is "a political issue of confluence, which brings together a range of services for people who are dependent on help in basic activities of daily living over an extended period of time". National definitions on longterm care vary within the European Union, and reflect the differences in the length of stay, range of beneficiaries and the often unclear boundary between health (health care) services and non-medical (social) services. Some countries prefer, for example, to focus on early rehabilitation outpatient treatment, while others focus more on providing care in hospitals or similar institutions. Long-term care can include rehabilitation, basic medical treatment, home health care, social care, housing and services such as transportation, food, occupational assistance and help in managing daily activities [11].

In the field of cross-border medical services, a certain overlap is somehow reached between the law of the Union and the national law, so that European law in many cases is essentially limited to indicating a binding objective, i. e. the achievement of the free movement of citizens patients and their equal treatment, regardless of nationality, in relation to national authorities, while preserving the competence of the member states. Directive 2011/24/EU preserves the competences of the Member States, which are obliged to submit to the regulatory framework imposed by primary law and secondary legislation, to the extent that Member States must not violate EU law when exercising their powers.

As argued in the Watts judgment, Member States are obliged to adapt their national healthcare and social security systems [12]. Moreover, the Court emphasized since its previous decisions that Member States must comply with EU law, in particular with the provisions on the freedom to provide services [13].

Those provisions prohibit Member States from introducing or maintaining unjustified restrictions on the freedom to provide of medical care services [14].

In addition, the Court case law expressly emphasized that the mandatory adaptations of national social security systems aiming to achieve the fundamental freedoms guaranteed by the Treaty should not be considered by Member 
States as interference in their sovereign competence in the field of public health [15].

We believe that should not remain unmentioned the fact that the European Union can exert considerable influence on the health systems of Member States, for example, by measures designed to achieve fundamental freedoms [16].

The Directive is without prejudice to the laws, regulations and administrative provisions of the Member States relating to the organization and financing of healthcare in situations not related to cross-border healthcare. In particular, nothing in this Directive obliges a Member State to reimburse the costs of healthcare provided by healthcare providers established on its territory if those providers are not part of the social security system or national health system of that State Member State.

From the interpretation of the text, in conjunction with Article 3, paragraph 1 letters (a) - (c) of Directive 2005/36/EC, follows that it does not matter whether the work performed by a qualified person (as is the sanitary field, such as the analysed case) has a temporary or occasional basis. As the promotion of the provision of services must be ensured in the context of the strict compliance with public health and safety and the protection of the consumer, Member States have special provisions in the national legislation for professions regulated at sector level with implications in terms of health.

Given the different systems established on the one hand, for the provision of temporary and occasional crossborder services and, on the other hand, for establishment, it is necessary to specify criteria for distinguishing between these two concepts in the case of the movement of the service provider on the territory of the host Member State.

The fundamental right to privacy with regard to the processing of personal data is protected in conformity with Member States' national measures for implementing Union provisions on the protection of personal data, in particular Directives 95/46/EC [17] and 2002/58/EC [18].

For a better understanding of this issue, we shall discuss the laws of Romania concerning the processing of personal data and on the free movement of such data, Law no. 677 of 2001 [19], to analyse how these rules apply to public health in general and, in particular, on cross-border healthcare.

Thus, the processing of personal data related to racial or ethnic origin, political, religious, philosophical or similar nature opinions, the union membership, as well as personal data concerning health or sex life is prohibited. This provision shall not apply where the subject has given their express consent to such processing.

Regarding the prior express consent we believe that, regarding healthcare, the mere presentation of the patient to a health service provider, amounts to a tacit consent, so we cannot discuss express consent. It is inevitable that the supplier request personal data, even for an appointment for diagnosis, (name, address, telephone number, affection suspected or confirmed by someone else etc. ).

The National Law, Law no. 677/2001, provides for special rules on the processing of personal data concerning health. According to this regulation, healthcare professionals, medical care institutions and their staff may process personal data on health status, without the authorization of the supervisory authority, only if the processing is necessary to protect the life, physical integrity or health of the concerned person.

To detail how personal data concerning health can be processed by service providers, the law provides that this operation can be performed only by a health professional or under its supervision, subject to professional secrecy.

We believe that the competent national authorities in public health should regulate more differentiated all aspects of the patient's right to confidentiality, to reduce the risks of disclosing personal data on the health of citizens. In our opinion and in the absence of these legislative differentiations, information that normally would not be provided to the public appears in the mass media.

\section{Conclusions}

Within health systems throughout the European Union there are a number of common principles of operation [20], which have been affirmed by the case law of the Court of Justice of the European Union. These principles must be applied uniformly in national health systems, both to strengthen the confidence of patients in cross-border healthcare, a prerequisite for achieving patient mobility, and to ensure a high level of health protection.

Referring to the decisions of national authorities on market mechanisms and the pressure of competition to manage health systems, the Council was of the view that decisions about the health care package which citizens are entitled to and the respective mechanisms used to finance and provide healthcare, must be placed in the national context of the Member States.

Under the Treaty on the Functioning of the European Union [21], at the basis of all European policies lies the aim to ensure a high level of human health protection, a major goal of the whole Union. This goal is also considered when the 
European legislator adopts acts under other Treaty provisions.

Most of the provisions of Directive 2011/24/EU aim to improve the functioning of the internal market and free movement of goods, persons and services in healthcare. Given this, the legal basis for the adoption of Directive 2011/24/EU is found in Article 114 TFEU. Union legislation is based on this legal basis even when public health protection is a decisive factor in the choices made, Article 114 TFEU explicitly stating that in this regard, a high level of human health protection must be ensured, taking account in particular of any new development based on scientific data.

From the case law of the Court of Justice of the European Union unequivocally results that people normally resident in a Member State operating a national health service, are entitled to receiving hospital treatment in another Member State at the expense of the national health service.

Member States may condition this right by the requirement that the person concerned should have obtained prior authorization, only if such authorization is based on objective, non-discriminatory and transparent criteria within a procedure system. In addition, applications for the authorization of treatment abroad must be analysed objectively and impartially, within a reasonable time, and the national health authority's refusal to grant such authorization can be challenged in court or out of court. The absence of such criteria and the lack of easily accessible and transparent procedures cannot deprive a person of this right. Also, if the conditions for authorization (form E112) are designed to safeguard the financial stability of the national health system, considerations of a purely budgetary or economic nature cannot justify a refusal to grant such authorization.

To determine whether the treatment is available without undue delay might be considered the waiting time and the priority to treatment granted by the national health authority, only on condition that they are based on concrete indications relating to the patient's condition at the time of evaluation, as well as its medical history and the prognosis for the patient seeking treatment.

Under European law, the affiliate Member State is obliged to fund the hospital treatment carried out in another Member State and the reimbursement of this treatment is based on national legislation. In the absence of tariffs or rates for calculating the amount of reimbursement, the reimbursement must be calculated at the actual cost of the treatment. Travel and accommodation costs related to hospital treatment received in another Member State are reimbursable only where this is provided for by national law for treatment on national territory.

Regarding the obligation of a Member State to reimburse the cost of hospital treatment provided in another Member State of the European Union, Article $49 \mathrm{EC}$ does not allow to take into account budgetary reasons, unless it is demonstrated that compliance with this obligation on a more general scale would threaten the financial balance of the respective national health system. Moreover, in accordance with Article 22 (2) of Regulation EEC No. 1408/71 [22], budgetary considerations cannot be taken into account in decisions refusing prior authorization for treatment abroad.

\section{References}

Charter of Fundamental Rights of the European Union (2012/C 326/02), Official Journal of the European Union C 326, 26. 102012.

Directive 2011/24/EU of the European Parliament and of the Council of 9 March 2011on the application of patients' rights in cross-border healthcare, Official Journal of the European Union L 88, 4. 4. 2011.

Council of the European Union, Council Conclusions on Common Values and Principles in European Union Health Systems, Official Journal of the European Union C 146/01, 22. 6. 2006.

European Commission, Communication from the Commission, Annual Growth Survey 2013 - COM (2012) 750 final, 28. 11.2012.

European Commission, Communication from the Commission, Europe 2020 A strategy for smart, sustainable and inclusive growth, COM (2010) 2020 final, Brussels, 3. 3. 2010.

European Commission, Commission White Paper Together for Health: A Strategic Approach for the EU 2008-2013, COM (2007) 630 final, 23. 10. 2007.

European Commission, Commission Staff Working Document, Investing in Health, Social Investment Package, SWD (2013) 43 final, February 2013, Brussels, 20. 02. 2013.

Directive 2006/123/EC of the European Parliament and of the Council of 12 December 2006 on services in the internal market, Official Journal of the European Union L 376, 27. 12. 2006, p. 36.

Council of the European Union, Council Conclusions on Common values and principles in European Union Health Systems, Official Journal of the European Union C 146, 22. 6. 2006

Treaty of Lisbon amending the Treaty on European Union and the Treaty establishing the European Community, signed at Lisbon, 13 December 2007, Official Journal of the European Union C 306, 17. 12. 2007.

OECD/European Commission, A Good Life in Old Age? Monitoring and improving quality in long-term care, OECD Health Policy Studies, OECD Publishing, 2013.

Judgment of the Court (Grand Chamber) of 16 May 2006. The Queen, on the application of Yvonne Watts v Bedford Primary Care Trust and Secretary of State for Health. Reference for a preliminary ruling: Court of Appeal (England \& Wales) (Civil Division) - United 
Kingdom. Social security - National health system funded by the State - Medical expenses incurred in another Member State Articles 48 EC to 50 EC and 152 (5) EC - Article 22 of Regulation (EEC) No 1408/71. Case C-372/04 Watts, paragraph 147.

See: Judgment Smits and Peerbooms (Case C-157/99 Rec. , 2001, I-5473, paragraphs 44 to 46), Judgment Müller Fauré și van Riet (Case C-385/99 Rec. , 2003, I-4509, paragraph 100), Judgment Inizan (Case C-385/99 Rec. , 2003, I-04509, paragraph 17) and Judgment Commision/Spain (Case C-211/08 Rec. , 2010, p. I-5267, paragraph 53).

In this respect, see Judgment of 19 April 2007, Stamatelaki (C-444/05, Rep. , p. I-3185, paragraph 23) and Judgment of 5 October 2010, Elchinov (C-173/09, Rep. , p. I-8889, paragraph 40).

This idea is clearly expressed in Judgment Commission/Luxembourg (C-490/09, Rec. , 2011, p. I-247, paragraph 32)

See e. g. Judgment of 3 October 2000, Ferlini (C-411/98, Rec. , p. I-8081, paragraph 47 et seq. ), Judgment of 9 September 2003, Jaeger (C-151/02, Rec. , p. I-8389), in terms of services provided by a doctor on call in a hospital about the safety and health of workers, Judgment of 11 December 2003 Deutscher Apothekerverband (C-322/01, Rec. , p. I-14887), concerning the national ban on the marketing of medicinal products by mail order and Judgment of 18 March 2004, Leichtle (C-8/02, Rec. , p. I-12641, paragraph 51), on the conditions for reimbursement of the expenses for treatment carried out in another member state.

Directive 95/46/EC of the European Parliament and of the Council of 24 October 1995 on the protection of individuals with regard to the processing of personal data and on the free movement of such data, Official Journal of the European Union L 281, 23. 11. 1995.

Directive 2002/58/EC of the European Parliament and of the Council of 12 July 2002 concerning the processing of personal data and the protection of privacy in the electronic communications sector (Directive on privacy and electronic communications), Official Journal of the European Union L 201, 31. 7. 2002, p. 37.

Law no. 677/2001 on the protection of persons with regard to the processing of personal data and the free movement of such data, published in the Official Monitor of Romania, Part I, no. of 12 December 2001, with the subsequent modifications and completions.

Council of the European Union, Council Conclusions on Common values and principles in European Union Health Systems (2006/C 146/01), Official Journal of the European Union C 146, 22. 6. 2006, p. 2.

The Treaty on the Functioning of the European Union (consolidated version) TFEU, Official Journal of the European Union C $326,26$. 10. 2012, article 168, paragraph (1).

Regulation (EEC) No 1408/71 of the Council of 14 June 1971 on the application of social security schemes to employed persons and their families moving within the Community, Official Journal of the European Union L 149, 5. 7. 1971. 